\title{
Analysis of Factors Affecting Tuber Consumption Based on Income Classes at Palembang City Indonesia
}

\author{
Yudhi Zuriah Wirya Purba ${ }^{\mathrm{a},}$, Agoes Thony $\mathrm{Ak}^{\mathrm{a}}$ \\ ${ }^{a}$ Department of Agribusiness Science, University of Sjakhyakirti, Jl. Sultan Muh.Mansyur Kebon Gede, Palembang, Indonesia \\ E-mail: "yudhi.wardi@yahoo.com
}

\begin{abstract}
The research objective was to analyze factors affecting tubers consumption in Palembang City based on income classes. This study was conducted at Ilir Barat I, Ilir Timur II, and Seberang Ulu II Sub-districts, Palembang City, South Sumatra, Indonesia. This research aims to identify the factors that could affect the consumption of tubers based-on income classes in Palembang city as the capital of South Sumatra. This research data collection through a survey method that collected samples using the disproportioned stratified random sampling technique consisting of 90 heads of families from 3 (three) districts in Palembang. Data were analyzed using multiple linear regression analysis. The results of the research are the factors identified to have a significant effect on the consumption level of tubers. These factors are family size (number of family members), prices of noodles, price of cassava, price of sweet potato, age composition, housewife educational levels, and household income levels. The results concluded that the cassava and sweet potato price had significantly positive contributions. In contrast, the mediaum and high income had significant negative effects on tubers consumption in Palembang City. Moreover, as for the rest, the family size, instant noodle price, age composition, and housewife educational level had no significant effect.
\end{abstract}

Keywords - income classes; production factors; tubers consumption.

\section{INTRODUCTION}

Although generally, local foods of non-rice are relatively diverse in Indonesia, most Indonesians rely solely on paddy rice as their staple food [1] and in Palembang [2]. The consumption of rice in Indonesia reached 81.86 $\mathrm{kg} /$ capita/year in 2017 [3]. This consumption number comprises all types of processed rice, such as cooked rice, steamed rice in a banana leaf (lontong) or a coconut leaf (ketupat). And snacks made of steamed glutinous rice (Lemper) and a wide variety of home-made cookies of rice flour, which might serve in restaurants or vendors as well. Besides, as the consumption for the cooked rice alone is $61.34 \mathrm{~kg} /$ capita/year [4], about $75 \%$ of all rice-based food consumption.

In comparison with the world's average rice consumption of only $60 \mathrm{~kg} / \mathrm{capita} /$ year, rice consumption in Indonesia was among the highest in Asia along with Japan (60 kg), Malaysia (80 kg), and Thailand (90 kg) [5]. In Palembang, one of the major cities in Indonesia with a population of $1,623,099$ in 2017 , rice consumption reaches 16,966 tons annually [6]. This high demand inadequately sustained by the rice production in Palembang alone due to an urbanized area that relied on the commercial sector instead of agriculture [2]. Most agricultural products were brought from the neighboring Palembang regions, such as Banyuasin, Ogan Komering Ulu, Ogan Komering Ilir, and Muara Enim Regency [6]. Based on analysis from the Indonesian Society of Medical and Nutrient Physicians (PDGMI), tapioca provides more calories than potatoes, corn, rice, instant noodles, and bananas [7]. In every 100-gram serving, tapioca provides 363 calories, the highest among others as in rice, instant noodle, potatoes, corn, sweet potatoes and bananas that provides 335 calories, 337 calories, 83 calories, 129 calories, 123 calories, and 88 calories respectively [8] (see the fig 1).

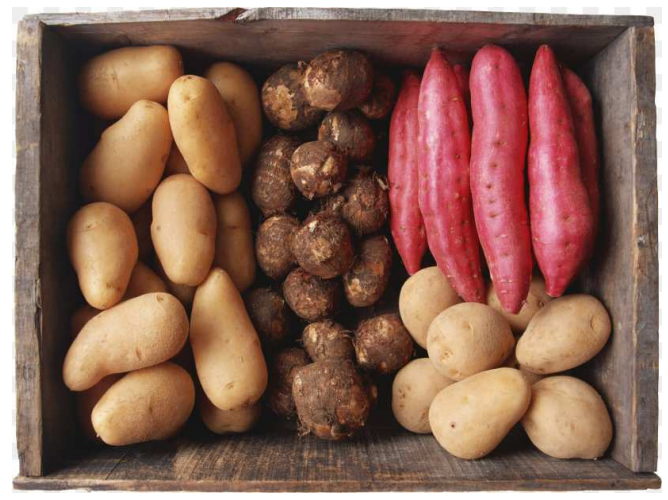

Fig. 1 Image of Cassava and Sweet Potatoes 
A potential substitute for reducing instant noodle consumption is tubers that comprise to cassava and sweet potatoes [9]. The choice of tubers as a substitute for instant noodle consumption is justifiable due to their abundance and relatively cheap besides its quite costly of calories (every 100-gram serving, tubers provides 157 calories while instant noodle only provides 117 calories [10]. Formerly, it is still quite rare among researchers to find a study referred to the tuber's potential as a food resource. Therefore, it is essential to investigate tubers potential as a substitute staple food to rice and instant noodle, particularly in the case of Palembang City. Hence, the problem statement formulated to this study is "what factors of tubers consumption based-on income classes in case of Palembang City?"

\section{MATERIALS AND METHOD}

\section{A. The Research Objective, Location and Time}

The objective of this research is to analyze the factors that affect tubers consumption based on income class in Palembang City. Location selection was made by using multi-stage cluster sampling [11]-[13] based on income cluster (block). The site selection started from the scope of the entire city of Palembang and further expanded into district, subdistrict and village unit and eventually to each householder. This arrangement considers the widespread distribution of those observed population.

\section{B. Research Method and Sampling Technique}

The method used in this study surveyed to collect data on the field [14]-[16]. The data collection method is disproportioned stratified random sampling [11], [17], [18] that was proportionally obtained from each income-based population class. It comprises low-income (underprivileged), middle-income (prosperous family II), and high-income (prosperous family III), as shown in Table I.

TABLE I

Population AND SAMPle of FAMILIES OF Low, MEdium AND High INCOMES IN PALEMBANG CITY

\begin{tabular}{|c|l|l|l|c|c|}
\hline No & \multicolumn{1}{|c|}{$\begin{array}{c}\text { Income } \\
\text { Class }\end{array}$} & $\begin{array}{c}\text { District } \\
\text { (inhabitants) }\end{array}$ & $\begin{array}{c}\text { Sub- } \\
\text { district } \\
\text { (HoF) }\end{array}$ & $\begin{array}{c}\text { Sample } \\
(\mathbf{H o F})\end{array}$ & $\begin{array}{c}\text { Percentage } \\
(\%)\end{array}$ \\
\hline 1 & $\begin{array}{l}\text { Low (pre- } \\
\text { prosperous) }\end{array}$ & $\begin{array}{l}\text { Seberang Ulu } \\
\text { II 3.525 }\end{array}$ & $\begin{array}{l}16 \text { Ulu } \\
579\end{array}$ & 30 & 5.18 \\
\hline 2 & $\begin{array}{l}\text { Middle } \\
\text { (prosperous } \\
\text { II) }\end{array}$ & $\begin{array}{l}\text { Ilir Timur II } \\
17.314\end{array}$ & $\begin{array}{l}3 \mathrm{Ilir} \\
3.189\end{array}$ & 30 & 0.94 \\
\hline 3 & $\begin{array}{l}\text { High } \\
\text { (prosperous } \\
\text { III*) }\end{array}$ & $\begin{array}{l}\text { Ilir Barat } \\
\text { I7.744 }\end{array}$ & $\begin{array}{l}\text { Bukit } \\
\text { Lama } \\
377\end{array}$ & 30 & 7.96 \\
\hline
\end{tabular}

Remarks : $\mathrm{HOF}=$ Head of Family.

\section{Data Processing Method}

The data obtained from the survey are sorted into groups and arranged in a tabulation. To answer the objective of this study, calculations method was implemented on tabulated data of instant noodle and tubers consumption as well as the consumption pattern and behavior of families. For example, whether instant noodles and tubers could substitute paddyrice as a main staple food or merely as complementary dishes. This data is required to answer the second objective of this study [12], [19]. To answer the first objective: to identify factors of tubers consumption based-on income classes in Palembang, a multiple regression analysis was carried out utilizing equation as follows [20]-[22] :

$$
\begin{gathered}
\mathrm{TC}=\alpha+\beta_{1} \mathrm{FS}+\beta_{2} \mathrm{NP}+\beta_{3} \mathrm{CP}+\beta_{4} \mathrm{SP}+\beta_{5} \mathrm{D}_{1}+ \\
\beta_{6} \mathrm{D}_{2}+\beta_{7} \mathrm{D}_{3}+\beta_{8} \mathrm{D}_{4}+\mathrm{e}
\end{gathered}
$$

Where:

$$
\begin{aligned}
\mathrm{TC} & : \text { Tubers Consumption }(\mathrm{kg}) \\
\alpha & : \text { Constanta } \\
\beta & : \text { Regression coefficient } \\
\mathrm{FS} & : \text { Family size } \\
\mathrm{NP} & : \text { Instant noodle price }(\mathrm{Rp} / \mathrm{kg}) \\
\mathrm{CP} & : \text { Cassava price }(\mathrm{Rp} / \mathrm{kg}) \\
\mathrm{SP} & : \text { Sweet potato price } \\
\mathrm{D} 1 \quad: \text { Age composition of families } & \\
& : 1 \text { if dominant ages are less than } 21 \text { years } \\
& : 0 \text { if dominant ages are minimum of } 21 \text { years } \\
\mathrm{D} 2 & : \text { Educational level of housewives } \\
& : 1 \text { if the educational level of homemakers is higher } \\
& \text { than Senior High School } \\
& : 0 \text { if the maximum educational level of homemakers is } \\
& \text { Senior High School } \\
\text { D3 } \quad: \text { Medium level of household income } & : 1 \text { if household incomes are medium } \\
& : 0 \text { if household incomes are not medium } \\
\text { D4 } & : \text { High level of household income } \\
& : 1 \text { if household incomes are high } \\
& : 0 \text { if household incomes are not high }
\end{aligned}
$$

Model validation was determined from the coefficient of determination $\left(\mathrm{R}^{2}\right)$. The higher the value of $\mathrm{R}^{2}$, the greater chance to explain the change in the dependent variable from independent variables. The adjusted coefficient of determination $\left(\operatorname{Adj}-\mathrm{R}^{2}\right.$ ) will be better if it is closer to the determination coefficient value [23], [24]. The equation used to calculate $\mathrm{R}^{2}$ value is as follows:

$$
\mathrm{R}^{2}=\frac{J K_{\text {regression }}}{J K_{\text {total }}}
$$

Because the data used to conduct the estimated equation in this study was cross-section data, then further analysis is needed to determine the probability of multicollinearity occurrence [25], [26]. The existence of significant multicollinearity on the estimated model will result in a low level of estimation accuracy, which subsequently produces inaccuracy of the estimated model. To solve this problem, test of the partial regression coefficient for each dependent variable was performed as well as the calculation of the partial correlation coefficient of each dependent variable [19]. The precision of the developed model was determined by conducting a statistical analysis of F-test through proposed hypothesis as follows:

$$
\begin{aligned}
& \text { Ho }: \beta_{i}=0 \\
& \mathrm{H}_{1}: \text { one of } \beta_{\mathrm{i}} \neq 0, \text { where } \mathrm{i}=1,2,3,4,5,6 \text { and } 7
\end{aligned}
$$


If $\mathrm{F}_{\text {calculated }}<\mathrm{F}_{\text {table, }}$, then Ho is accepted, which means that none of the independent variables is significant to the consumption of instant noodles/tubers. On the other hand, if $\mathrm{F}_{\text {calculated }}>\mathrm{F}_{\text {table }}$, then $\mathrm{H}_{\mathrm{o}}$ is rejected, and $\mathrm{H}_{1}$ is accepted, which means that all independents variables are simultaneously significant to the consumption of instant noodles/tubers. The following equation is used to calculate the statistical value of $\mathrm{F}\left(\mathrm{F}_{\text {calculated }}\right)$.

$$
F_{\text {calculated }}=\frac{J k_{\text {regression }} / k}{J k_{\text {residual }} /\left(\begin{array}{lll}
n & k & 1
\end{array}\right)}
$$

Where:

$\mathrm{k}=$ number of variables in the model equation $\mathrm{n}=$ number of observed samples

The T-test was conducted to determine the partial effect of independent variables on the dependent variable within the estimated regression equation. The proposed hypothesis is as follows:

$$
\begin{aligned}
& \mathrm{H}_{\mathrm{o}}: \beta_{\mathrm{i}}=0 \\
& \mathrm{H}_{1}: \beta_{\mathrm{i}} \neq 0, \text { where } \mathrm{i}=1,2,3,4,5,6 \text { and } 7
\end{aligned}
$$

If $t_{\text {calculated }}>t_{\text {table }}$ in this hypothesis test, then it is decided to reject $\mathrm{H}_{\mathrm{o}}$, which means that independent variables are partially significant to rice consumption. If $t_{\text {calculated }}<t_{\text {table }}$, then Ho is accepted, which means independent variables partially are not significant to the consumption of instant noodles/tubers. The following equation is used to calculate the statistical value of $\mathrm{t}\left(\mathrm{t}_{\text {calculated }}\right)$ :

$$
|t|_{\text {calculated }}=\frac{\beta i}{\operatorname{Se}(\beta i)}
$$

where $\operatorname{Se}(\beta i)=\sqrt{\operatorname{var} i a n(\beta i)}$

where :

$\beta_{i}=$ Partial regression coefficient for independent variables of i-th

Se $\left(\beta_{i}\right)=$ Standard error of $\beta_{i}$

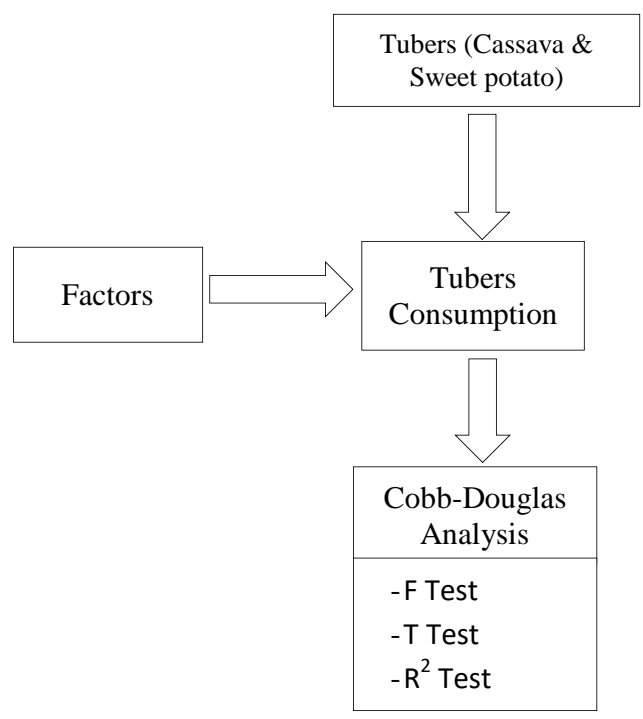

Fig. 2 Diagrammatic model of the relationship between tubers consumption and Cobb-Douglas Analysis
To examine this research thoroughly starts from the fact that tubers of both types (cassava and sweet potatoes) are substitutive to paddy-rice along with instant noodles and many other types that are considered in Indonesia as a staple food. Based on this fact, undeniably, the presence of tubers as substitutive staple food would create demand. This demand would trigger the consumption, particularly on tubers in this research. To elaborate and deepen the understanding of this tuber's consumption, then some factors are identified that presumably affect the tuber consumption. Furthermore, the characteristics of those factors would be identified by the research analysis method on the data collected from a direct interview in a survey. The analysis method used in this research is a multivariate regression, particularly a Cobb-Douglass type model (see Fig 2).

\section{RESULTS AND DISCUSSION}

\section{A. The Factors which Influences of Tuber Consumption}

The estimated factors, which affect the character of tubers consumption in Palembang City, are identified as follows: family size (FS), price of instant noodle (NP), cassava price (CP), sweet potato price (SP), a dummy of age composition (D1), dummy of housewives educational level (D2), dummy of medium-income (D3) and dummy of high income (D4). Two regression models used in this study are linear regression and Cobb-Douglas type regression [27]. The results showed that Cobb-Douglas type regression model had produced better results determined by a greater value of determination coefficient (R2). The estimating equation was formulated by using Cobb Douglas type regression, and the result was given in Table II as follows.

\begin{tabular}{|c|c|c|c|c|c|c|}
\hline \multirow[t]{2}{*}{ No } & \multirow{2}{*}{ Parameters } & \multirow{2}{*}{$\begin{array}{l}\text { Estimated } \\
\text { parameters }\end{array}$} & \multirow{2}{*}{ t-Value } & \multirow{2}{*}{$\begin{array}{c}\text { Error } \\
\text { probability }\end{array}$} & \multicolumn{2}{|c|}{$\begin{array}{l}\text { Statistics of } \\
\text { collinearity }\end{array}$} \\
\hline & & & & & Tol & VIF \\
\hline 1 & Intercept & -7.570 & -1.465 & $0.147 \mathrm{~d}$ & & \\
\hline 2 & $\begin{array}{l}\text { Logarithm of } \\
\text { family size (FS) }\end{array}$ & -0.221 & -1.188 & $0.238 \mathrm{e}$ & 0.799 & 1.252 \\
\hline 3 & $\begin{array}{l}\text { Logarithm of } \\
\text { instant noodle's } \\
\text { price (NP) }\end{array}$ & -0.894 & -0.783 & $0.436 \mathrm{e}$ & 0.736 & 1.359 \\
\hline 4 & $\begin{array}{l}\text { Logarithm of } \\
\text { cassava's price } \\
\text { (CP) }\end{array}$ & 1.751 & 2.074 & $0.041 \mathrm{~b}$ & 0,105 & 9.510 \\
\hline 5 & $\begin{array}{l}\text { Logarithm of } \\
\text { sweet potato's } \\
\text { price (SP) }\end{array}$ & 1.511 & 2.218 & $0.029 b$ & 0.260 & 3.849 \\
\hline 6 & $\begin{array}{l}\text { Age composition } \\
\text { of family member } \\
\text { (D1) }\end{array}$ & 0.131 & 1.263 & $0.210 \mathrm{e}$ & 0.716 & 1.397 \\
\hline 7 & $\begin{array}{l}\text { Educational level } \\
\text { of housewives } \\
\text { (D2) }\end{array}$ & 0.098 & 0.837 & $0.405 \mathrm{e}$ & 0.419 & 2.384 \\
\hline 8 & $\begin{array}{l}\text { Medium- income } \\
\text { level (D3) }\end{array}$ & -0.909 & -8.341 & $0.000 \mathrm{a}$ & 0.438 & 2.282 \\
\hline 9 & $\begin{array}{l}\text { High-income } \\
\text { level (D4) }\end{array}$ & -1.303 & -6.009 & $0.000 \mathrm{a}$ & 0.109 & 9.194 \\
\hline & & $\mathrm{R} 2=66.10$ & 19.506; & $=0.999$ & & \\
\hline
\end{tabular}

\section{TABLE II}

PARAMETER ESTIMATION VALUES FROM REGRESSION ANALYSIS FOR TUBERS CONSUMPTION AT PALEMBANG CITY

Remarks:

$\mathrm{a}=$ Significant at error level of $1 \%$

$\mathrm{b}=$ Significant at error level of 5\%

$\mathrm{c}=$ Significant at error level of $10 \%$

$\mathrm{d}=$ Significant at error level of $15 \%$

$\mathrm{e}=$ Not significant at maximum error level of $15 \%$ 


\section{B. The Criteria of Economic}

The criteria of economic-based on the economic theory present the results of the analysis of those identified some factors. This research also highlights the parameters regarding the tuber's consumption as the center of the hypothesis and research goal of this study. Any findings on this part would lead to any clue that would bring this research a step forward to answer the main research question before any further analysis.

The results of the estimated equation could be considered as adequately suitable to the economic theory expectation based on the economic criteria because 4 (four) out of 8 (eight) independent variables correspond to economic theory expectation as follows: dummy variable of age composition, housewife educational level, medium-income level, and high-income level. Dummy variable of age composition has positive value and suit to economic theory expectation which indicates that mostly younger family member tends to consume more tubers. However, the results of t-test were not quite significant. The estimated parameter of housewife's educational level has a positive value and suit to economic theory. It means that better-educated homemakers tend to consume more tubers rather than to those with lower educational levels even though not quite significant. Families with variables of medium-income level and highincome level had consumed tubers in lower quantity than that of low-level income.

On the other hand, the variable which its parameter that does not adequately suit economic theory expectations are all related to the price: the instant noodle's price, cassava's price, and sweet potato's price. The instant noodle's price which supposed to be optimistic regarding its potential as tubers substitutive staple food, but instead, it's negative, also, with the cassava's price and sweet potato's price which both are tubers themselves. According to the economic theory, those price parameters are supposed to have negative values to the tuber's consumption regarding the cost and supplydemand law of economics. But instead, they have positive ones.

From these findings, some explanations could be formulated that the instant noodle and tubers are not substituting each other. Both instant noodle and tubers had their typical consumer with the consumption behavior on staple food, which related more to any other factors rather than a price comparison between instant noodles and tubers. As for the cassava's price and sweet potato's cost, which both technically made the tuber's price that in nature should have negative to the tuber's consumption but surprisingly, they have positive values instead. Normally and "ceteris paribus"-ly, the economic theory expects an opposite behavior between price and consumption that indicate a less to consume when the price rise. But it's apparently could not be considered working in the "ceteris paribus" term. As in the instant noodle, the tubers are likely an alternative staple food substituting the paddy-rice, which is still consumed by most Indonesians. But in the times when the paddy rice's price rise as for example, during the vesting month in Ramadhan. Mainly these are times when the demand is escalating massively, not only affecting the rice's price but also most of the other goods of primary needs. Or in recession times such as an economic crisis, a prolonged drought, or any other severe natural disasters which enormously affecting both the production and supply. Tubers, as for both the cassava and the sweet potatoes are known to be one among the most accessible foods to grow in a relatively short time and high quantity. That fact makes the tubers as one of the best choices for people to consume while all other primary need's prices rise so that they could save some money. Thus, the causality between the tuber's price and consumption is in reversed-way. The consumption does not follow the price change. On the contrary, the tuber's price follows consumption.

In other words, it's unlikely fewer tubers to consume because of its price rise. But it is instead that the tuber's price rise because people consume it much more due to its comparative price with other staple foods. The estimated results of Table II can be transposed into a regression equation as follows:

$$
\begin{gathered}
\mathrm{TC}=2,69 \times 10^{-8} \mathrm{FS}^{-0,221} \mathrm{NP}^{-0,894} \mathrm{CP}^{1,751} \mathrm{SP}^{1,511} \\
\mathrm{e}^{0,131 \mathrm{D}_{1}} \mathrm{e}^{0,098 \mathrm{D}_{2}} \mathrm{e}^{-0,909 \mathrm{D}_{3}} \mathrm{e}^{-1,303 \mathrm{D}_{4}}
\end{gathered}
$$

$\log \mathrm{TC}=-7,570-0,221 \mathrm{Log} \mathrm{FS}-0,894 \mathrm{Log}$

$$
\begin{gathered}
\mathrm{NP}+1,751 \log \mathrm{CP}+1,511 \operatorname{LogSP}+0,131 \mathrm{D}_{1}+0,098 \mathrm{D}_{2^{-}} \\
0,909 \mathrm{D}_{3}-1,303 \mathrm{D}_{4}
\end{gathered}
$$

Tubers' price is indeed relatively lower than any other staple food. Therefore, if there's a significant increase in prices, it is quite related to the rise of tuber's consumption due to the higher quantity being bought as an alternative staple food. Price is one of the instruments used to determine consumer's behavior in choosing their consumer products [28]. These 3 (three) variables that do not suit the economic theory are all related to the price, and it is not merely by a coincident. Moreover, this finding may lead to a further important presumption: neither the tubers nor the instant noodles should be conducted merely based on its supply-side without considering the main staple food. Yet, the paddyrice still the most consumed staple food that dramatically affects the demand of the tubers and the instant noodles as well. A brief recall would bring us back to the fact of the research method that the tubers of both types (cassava and sweet potatoes) are substitutive to paddy-rice along with instant noodles. And there should be more factors to be identified. Thorough these other factors could explain better how the tubers relate to the other staple foods.

\section{The Statistical Criteria}

In the statistical criteria, the examination of this research would be conducted mainly to determine the two essential statistical indicators, the significance and the issue of collinearity, which affect the validity of whether the data collection, data processing, and the analysis are particularly related to the statistical criteria.

Based on statistical criteria [29], the regression equation of factor analysis on tuber's consumption is considered acceptable regarding some major indicators such as R2 value, F-test value, and t-test value. Data shown in Table 2 indicated that $\mathrm{R}^{2}$ or coefficient of determination of 66.10 could be considered as high enough to determine a significant factor. Additionally, F value of 19.506 was relatively high and significant at an error level of one percent. 
Results of the t-test individually had produced four variables, which were significant at the error level up to 15 percent, as well as the other four variables, which were not significant. However, the estimated equation had no collinearity problem based on econometric criteria. The VIF values less than 10, and tolerance values higher than 0.10 . Therefore, it is in low probability of autocorrelation occurrence due to the time series data used. And, the dw value of 0.999, which indicated no autocorrelation occurs. Subsequently, the estimated equation also had no heteroscedastic problem, which was shown from scatter diagram that produced irregular data scattering or without specific pattern (no occurrence of the heteroscedastic problem).

The effect of each variable on tuber consumption could be indicated from the estimated parameter values. In the case of Cobb Douglas-type regression equation, these values were automatically equal to elasticity values. The estimated parameter of family size was -0.221 , and the results of the ttest showed that it was not significant at an error level of 15 percent. That means the family size did not correlate tubers consumption because not all family members consume tubers, especially those of green or raw ones. The consumption of tubers depends on individual knowledge about the benefit of tubers for health. Results of t-test showed that the estimated parameter of instant noddle's price had no significant effect on tubers consumption, which indicate that instant noodle will not substitute tubers as a staple food. Otherwise, tubers won't substitute instant noodles either.

\section{The Effect of Cassava and Sweet Potato's Price}

The results of the t-test showed that variables of cassava's price and sweet potato's price had significant effects. The estimated parameter value of cassava's price was 1.751, which means that a 1 percent increase in cassava's price would increase the sweet potato's price by about 1.751 percent and vice versa in caters paribus condition. The relation between cassava consumption and cassava's price was classified as elastic because its value is greater than 1 . Sweet potato's price had similar characteristics with cassava's price, although its elasticity value was not greater than that of cassava elasticity, but it was still elastic. This condition showed that household which bought tubers at a higher price also consumed high quantity of tubers. The positive and elastic signs of the estimated parameter showed that tubers would become a product with a higher value for households if its price were higher. Some remarkable sweet potatoes with relatively higher prices, such as Cilembu and purple sweet potato, might affect consumer behavior. The purple sweet potatoes that had been identified as having benefit effect on health might affect the age composition, income class and level of education.

\section{E. The Effect of Income Level}

The effect of dummy variables of income level showed that both medium income level and high-income level had significant effects with estimated parameter values of -0.909 and -1.303 , respectively. These values indicate that the tubers consumption might deviate between the mediumincome and non-medium-income (both low and highincome). This also applied as well between the high-income and non-high-income (both low and medium-income). These values could be interpreted that the tubers consumption of medium-income averagely 0.909 percent lower than those of low and high-income class. On the other hand, tubers consumption of high income averagely 1.303 percent lower than those of low and medium income.

Therefore, overall tubers consumption for households with low-income class was higher than that of medium income class and high-income class, in line with [30] that tuber's consumption is influenced by family income. The results showed that tubers consumption (cassava and sweet potato) of households with low-income class was $20.20 \mathrm{~kg}$ per month, whereas tubers consumption for households with medium income class and high-income class were 1.76 and $5.35 \mathrm{~kg}$ per month, respectively.

This finding is important to achieve a clearer understanding of the tuber's consumption along with other staple foods in Indonesia. In the previous important finding lead to the fact that the tubers are likely a substitutive food of the paddy-rice as well as in the instant noodles. But nevertheless, tubers and instant noodles are not substitutive to each other. Regarding the tubers as relatively cheaper and easier food to earn rather than any other, it's perfectly suitable to this income-related finding. The tubers consumption relatively much higher for low income rather than medium and high income. This finding also could explain better why both the cassava's price and sweet potato's price do not follow the economic theory to consumption. That the low incomes are the most consumers of tubers than any others while they still consume the paddyrice as a main traditional staple food, although in limited numbers. They would not consume more tubers just because it went cheaper since it's already the most affordable than the others. They seem to consume tubers more when the paddy-rice price higher, mostly if it went beyond their purchasing power. These all findings taught us an essential resolution to the importance of creating demand on tubers without reducing the supply of its first choice.

The demand of tubers from the medium and high income is apparently the better policy to be considered by decisionmakers, so the dependency on the paddy-rice could be reduced. And more variations of staple food are healthier and enable people to be more creative in creating and developing the variations of tubers-based dishes and better quality of serving, nutrition, and even prestige. It gradually could shift the general public perception that the tubers are for low income or poor.

It is important to enhance the appeal side of tubers rather than to enhance other factors such as family size, age composition, and housewife's' educational level, which are not significant, as explained below. The appeal of the tuber's quality should be enhanced in all parts of the production line. Form the tubers' plantations, food processing, food serving, and labeling when some creative dish made by tubers and succeed, the behaviors of tubers demand would likely change and considered as substitutive to paddy-rice in an equal level of quality and prestige. The more medium and high-class consuming tubers, the more workforce could be allocated to work on this promising commodity not only in plantations but also in the food processing factory, storage buildings, distribution chains (see the Fig 3 ). 


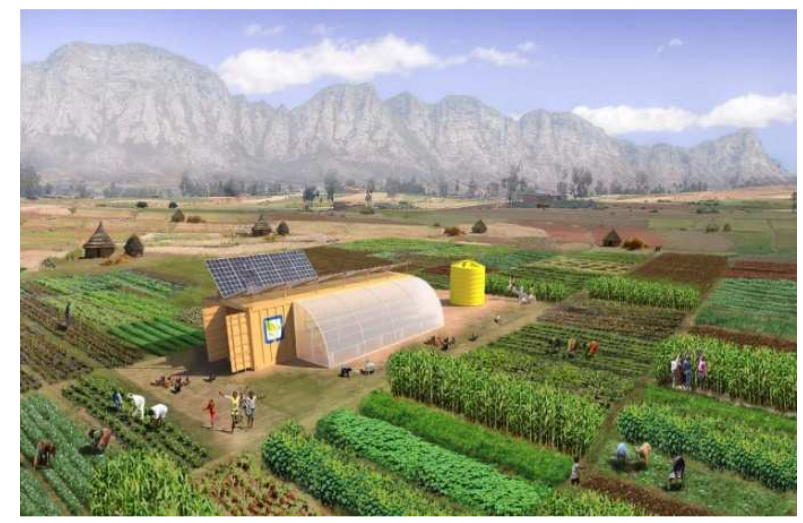

Fig. 3 The illustration of modern cassava's plantations and processing

\section{F. The Other Factors}

The rest of those observed factors that had been identified as insignificant statistically but would still use to comprehend the tubers consumption's behaviors regarding to those factors indicated by the positive or negative parameter value of each. The results of the t-test showed that family members, age composition and housewives educational level had no significant effect. This showed that there were no differences in tuber consumption between young family members and adult family members. Besides, no difference in tubers consumption between those with homemakers achieved higher than senior high school, and those that only graduated from senior high school. This condition again showed that not all family members consume tubers. An only particular spouse would consume tubers. Instead of the educational level of homemakers, it likely depended on the nutritional standpoint of tubers that benefit more for health. This statement is appropriate [29] that the level of education dramatically determines the choice of consumption through understanding the knowledge of nutrition, which beneficial for health.

\section{CONCLUSION}

Based on results of this study and discussion above might be concluded that factors that affect tubers consumption behavior in Palembang City were family member numbers, instant noodle's price, cassava's price, sweet potato's price, age composition, educational level of housewives, mediumincome level and high-income level. Also, factors that had a significant positive effect on tubers consumption behavior in Palembang City were cassava's price and sweet potato's price. At the same time, factors that had a significant negative effect were medium-income level and high-income level. On the other hand, factors of family size, instant noodle's price, age composition, and educational level of homemakers had no significant effect.

\section{REFERENCES}

[1] Roumasset JA. Rice and risk: decision making among low-income farmers.Amsterdam:North Holland. 1976.

[2] Food Tenacity Council of South SumatraProvince. Realizatiof Accelerated Food Consumption Diversification. Palembang. 2011.
[3] Hendriadi, Agung. This article has been published on Kompas.com with the title "Government Efforts to Lower Dependency on Rice Consumption".https://ekonomi.kompas.com/read/2017/10/25/065221 726/upaya-pemerintah-turunkan-ketergantungan-konsumsi-beras. Accessedat 26 January, 2018. 2017.

[4] Gilarso, T. Introduction to Microeconomics. Jakarta: Kanisius. 2011

[5] Wiryawan, G. Indonesia is The Highest Rice Consumption in the World. (Online). 2011.

(http://www.tempo.co/read/news/090371426/Konsumsi-Beras-diIndonesia-Tertinggi-di-Dunia, accessed at 12 December, 2011). 2011 .

[6] Statistical Center Council (BPS) of South Sumatra. 2018. Palembang in Numbers. Palembang. 2018.

[7] Dewi, P.S. Potential Analysis of Carbohydrate Source Food of NonRice in Relation to Household Characteristics at Palembang City. Thesis at Agrobusiness Study Program, Post Graduate Program of Sriwijaya University. Palembang. (Unpublished). 2013.

[8] Soetrisno, Heru. Pengukuran Berat Kalori dan Nilai Harga Kalori Menjadi Nilai Tukar Hakiki.. 2014 htps://www.academia.edu/8962410/Pengukuran Berat_Kalori_ dan_Nilai_ Harga_Kalori_Lampiran_Proposal. Diakses. $1 \overline{5}$ September 2018.

[9] Suparman. Bercocok Tanam Ubi Jalar. Azka Mulia Media. Jakarta. 2007.

[10] Michael Devega, Munyatul Islamiah, Kamaliah Ulfah. The Role of Modified Cassava Flour (Mocaf) as a Substitute for Wheat Flour in the Process of Making Noodles to Reduce National wheat imports. ITB Bogor. 2010.

[11] Gay, L.R. dan Diehl, P.L. Research Methods for Business and Management, MacMillan Publishing Company, New York. 1992.

[12] Hair, J.F., W.C. Black, B.J. Babin, R.E. Anderson, R.L.Tatham, Multivariate Data Analysis, 6 Ed., New Jersey: Prentice Hall. 2006.

[13] Sujarweni, V. Wiratna, Complete Practical and Easy to Understand Research Methodology, Yogyakarta: New Library Press. 2014.

[14] Frankfort-Nachmias, C. \& Nachmias, D. Research Methods in the Social Sciences. Fifth Edition. London: Arnold. 1996.

[15] Singarimbun, Masri dan Effendi, Sofian. Metode Penelitian Survai. Pustaka LP3ES. Jakarta Barat. 2006.

[16] Cholid Narbuko dan Abu Achmadi, Metodologi Penelitian, Jakarta: PT.Bumi Aksara, 2013

[17] Roscoe, J.T. Fundamental Research Statistics for the Behavioural Sciences, 2nd edition. New York: Holt Rinehart \& Winston. 1975.

[18] Silalahi, U. The Method of Social Science Research. PT. Refika Aditama. Bandung. 2009.

[19] Ghozali, Imam. Aplikasi Analisis Multivariate dengan Program IBM SPSS 23. Semarang: BPFE Universitas Diponegoro. 2016.

[20] Spiegel-R Murray. Elementary Sampling Theory, Theory and Problems of Statistic. Mc. Graw Hill Book, Company, C. 1972.

[21] Greene, W. Econometric Analysis (7th ed.). Boston: Pearson. 2012.

[22] Pardoe, Ian. Pemodelan Regresi Terapan. Newyork: John Wiley \& Sons. 2012.

[23] Sugiyono. Metode Penelitian Bisnis, Bandung: ALFABETA. 2012.

[24] Hartono, Jogiyanto. Metodologi Penelitian Bisnis. BPFE. Yogyakarta. 2014

[25] Gujarati, N.D. 2003. Basic Econometrics. 4th ed. New York: McGraw-Hill Companies, Inc.

[26] Widarjono, A. Ekonometrika: Teori dan Aplikasi untuk Ekonomi dan Bisnis. Edisi Kedua. Yogyakarta: Ekonisia Fakultas Ekonomi Universitas Islam Indonesia. 2007.

[27] Kutner, M.H., C.J. Nachtsheim., dan J. Neter. Applied Linear Regression Models. 5th ed. New York: Mc Graw-Hill Higher Education. 2020.

[28] Noel, Hayden. Basics Marketing 01: Consumer Behaviour. New York City: Bloomsbury Publishing. 2017.

[29] Sergeant, James. International Food Consumption Patterns and Global Drivers of Agricultural Production. United States: Nova Science Pubishers, Inc. 2015.

[30] Sahakian, Marlyne., Saloma, Czarina., and Erkman, Suren. Food Consumption in the City. 1st ed. England: Routledge. 2016. 